\title{
Isolation and characterization of 8 microsatellite loci for the "killer shrimp", an invasive Ponto-Caspian amphipod Dikerogammarus villosus (Crustacea: Amphipoda)
}

\author{
Tomasz Rewicz • Rémi A. Wattier • \\ Thierry Rigaud • Karolina Bacela-Spychalska • \\ Michal Grabowski
}

Received: 15 August 2013/Accepted: 12 September 2014/Published online: 19 September 2014

(C) The Author(s) 2014. This article is published with open access at Springerlink.com

\begin{abstract}
Dikerogammarus villosus is a freshwater amphipod of the Ponto-Caspian origin recognized as one of the 100 worst alien species in Europe, having negative impact on biodiversity and functioning of the invaded aquatic ecosystems. The species has a wide ecophysiological tolerance and during the last 20 years it has rapidly spread throughout European inland waters. In consequence, it presents a major conservation management problem. We describe eight polymorphic microsatellite loci developed for $D$. villosus by combining a biotin-enrichment protocol and new generation 454GS-FLX Titanium pyrosequencing technology. When genotyped in 64 individuals from two locations, the loci exhibited a mean diversity of 4.87 alleles per locus (2-13). The mean observed and expected heterozygosities were, respectively, $0.439(0.091-0.844)$ and 0.468 (0.089-0.843). Gametic disequilibrium was not detected for any pair of loci. The microsatellite markers will be a valuable tool in assessing the demographic processes associated with invasion of the killer shrimp from a genetic point of view.
\end{abstract}

Keywords Invasive species - Population genetics · Dikerogammarus villosus . Biological invasions . Polymorphic loci

T. Rewicz $(\bowtie) \cdot$ K. Bacela-Spychalska $\cdot$ M. Grabowski Department of Invertebrate Zoology and Hydrobiology, University of Lodz, 12/16 Banacha, 90-237 Lodz, Poland e-mail: tomek.rewicz@gmail.com

R. A. Wattier - T. Rigaud

Equipe Ecologie Evolutive, UMR CNRS 6282 Biogéosciences, Université de Bourgogne, 6 Boulevard Gabriel, 21000 Dijon, France

\section{Introduction}

The Ponto-Caspian amphipod Dikerogammarus villosus (Sowinsky, 1894), also known as the killer shrimp, is recognized as one of the 100 worst alien species in Europe [1]. This invader has colonized most of the European main inland water bodies in less than 20 years [2-4]. The threat it poses to ecosystems and species diversity is significant [5]. The killer shrimp is an efficient, high trophic level predator [6], feeding on other amphipods and on almost all other available benthic invertebrates [7, 8]. In addition, this species is characterised by wide ecophysiological tolerance to a number of environmental factors including water temperature, salinity and oxygen concentrations [9-12] as well as by very high fecundity [13-15]. Both features are highly advantageous in colonizing new areas. Initial expansion of D. villosus in continental Europe followed the two so-called invasion corridors for Ponto-Caspian fauna, associated with major rivers (i.e. the Southern Corridor via Danube/Rhine and the Central Corridor via Dnieper/Vistula) often referred to as "invasion highways" [2]. The populations migrating via the two invasion corridors originating in different Ponto-Caspian watersheds are about to come into contact in Poland [4] and possibly hybridize. Further expansion of the killer shrimp is currently in progress. It has recently colonized many lakes in the Alpine region [16] and was even accidentally introduced overseas to the UK [17]. Finally, the risk of its future introduction to the North American Great Lakes is not negligible.

The microsatellite markers will be a valuable tool in assessing the demographic processes associated with invasion of the killer shrimp from a genetic point of view. For example, they will help to identify the origin of populations in the UK and in Alpine lakes as well as to assess the dynamics of the invasion process (e.g. via the 
associated bottleneck or founder effect). Such marker will also help to estimate the differentiation between invasion corridors and chances for putative hybridization in case the two populations originating in different areas of the native range (Danube vs. Dnieper) meet in Poland. The three already known loci [18] proved to be useful [19] but additional loci are needed to answer more detailed questions.

\section{Materials and methods}

The total genomic DNA from eight $D$. villosus individuals was extracted with standard phenol-chloroform method. Enrichment for eight microsatellite motifs [i.e. $(A G)_{10}$, $(\mathrm{AC})_{10},(\mathrm{AAC})_{8},(\mathrm{AGG})_{8},(\mathrm{ACG})_{8},(\mathrm{AAG})_{8},(\mathrm{ACAT})_{6}$, $(\mathrm{ATCT})_{6}$ ] was based on a biotin protocol adapted from Kijas et al. [20]. The sequences were produced by pyrosequencing on a 454 GS-FLX Titanium ${ }^{\circledR}$ apparatus (Roche Diagnostics). Both, the enrichment and the pyrosequencing were as described by Malausa et al. [21]. Using the open access QDD program, the resulting 32,084 sequences were first screened for microsatellite (minimum of five repeats) and flanking sequences presence and then PCR primers were designed for selected sequences [22]. From a total of 4,206 candidate sequences including microsatellites, the primer design was effective for 102 putative loci. All the steps from enrichment down to primer design were performed at GenOSCREEN ${ }^{\circledR}$ (Lille, France). Thirty-three primer pairs were selected for amplification. Each forward primer was $5^{\prime}$ tailed with a M13 sequence (5'-AGGGTTTTCCCAGTCACGACGTT- $3^{\prime}$ ). The PCRs were carried out in a $10 \mu \mathrm{l}$ volume including $20 \mathrm{ng}$ DNA template, $200 \mathrm{nM}$ each primer (Table 1), $0.025 \mu \mathrm{M}$ of $5^{\prime}$ labeled M13 primer (either 700 or 800 dye), $5 \mu \mathrm{l}$ DreamTaq Master Mix (2x) DNA Polymerase (Thermo Scientific). The reactions were run in a BioRad thermocycler with an initial denaturation step at $95{ }^{\circ} \mathrm{C}$ for $3 \mathrm{~min}$, followed by 35 cycles consisting of $20 \mathrm{~s}$ at $95{ }^{\circ} \mathrm{C}, 45 \mathrm{~s}$ at $50{ }^{\circ} \mathrm{C}$ and $1 \mathrm{~min}$ at $72{ }^{\circ} \mathrm{C}$, and a final extension step at $72{ }^{\circ} \mathrm{C}$ for $2 \mathrm{~min}$. Product size variations was visualized with the LICOR 4200L automated sequencer. The polymorphism was tested on seven individuals from five locations in Europe: Liman Duru Golu, Turkey (41.316N; 28.621E); Danube delta, Ukraine (45.337N; 28.955E); Dnieper mouth, Ukraine (47.792N; 35.126E); Grafham water, UK $(52.292 \mathrm{~N}$; $-0.324 \mathrm{~W})$; Constance Lake, Germany $(47.748 \mathrm{~N} ; 9.137 \mathrm{E})$. From the 33 microsatellite loci chosen for amplification, ten failed to produce readable patterns, fifteen loci were monomorphic and eight primer pairs revealed polymorphism Further, the allelic diversity of the eight candidate loci was tested on 64 individuals, from the Danube delta in Ukraine (DAN; $n=32$ ) and from the Dnieper mouth in Ukraine (DNI; $n=32$ ). These two populations may be considered as representatives of the two distinct watersheds areas in the Ponto-Caspian region providing starting points for the killer shrimp invasion. The allelic diversity, observed (Ho) and expected (He) heterozygosities, deviations from Hardy-Weinberg proportions as well as gametic disequilibrium and differentiation between DAN and DNI (Fst as estimated by Weir and Cockerham Theta) were estimated using the software FSTAT version 2.9.3.2 [23]. When appropriate, the comparisons included Bonferroni correction for multiple tests. Presence and possible source of genotyping errors (null allele, stuttering, short allele dominance, [24] were checked with MicRO-CHECKER version 2.2.3. [25].

\section{Results and discussion}

Out of the 33 microsatellite loci chosen for testing, ten did not amplify at all, 15 were monomorphic and eight amplified successfully and revealed polymorphism.

Based on the 64 genotyped individuals from the Danube (DAN) and the Dnieper (DNI) populations, we obtained a mean diversity of 4.87 alleles per locus, ranging from 2 to 13 (Table 1). The mean observed and expected heterozygosities were, respectively, 0.439 (0.091-0.844) and $0.468(0.089-0.843)$. The Fstat software detected neither the gametic disequilibrium for any pair of loci, nor a deviation from the Hardy-Weinberg proportions in any locus in any of the two populations. However, MicRO-CHECKER detected sign of a null allele at Dv1 in both DAN and DNI and at Dv6 for DNI only. DAN and DNI populations were differentiated with a significant Fst value of 0.17. Although the invasion dynamics of the killer shrimp along the Danube and in French rivers was assessed by Wattier et al. [19] based on the three microsatellite loci available at that time [18], additional loci are needed for further assessment of its expansion all over Europe. The eight new loci will be highly valuable in identifying sources of introduction for the Alpine lakes and for the UK, that are not directly connected to any of the invasion highways (Fig. 1). The differentiation between DAN and DNI populations illustrates that such source populations could be relatively easily identified with a higher number of loci. Moreover, these markers could help to detect possible hybridization and/or introgression between the two populations of $D$. villosus which may become in contact in Poland [26].

Finally, it is known that microsatellite markers characterized for one species may often reveal polymorphism in other closely related taxa [27]. Thus we suggest that the loci described here have potential to be amplified in species closely related to the "killer shrimp" such as 






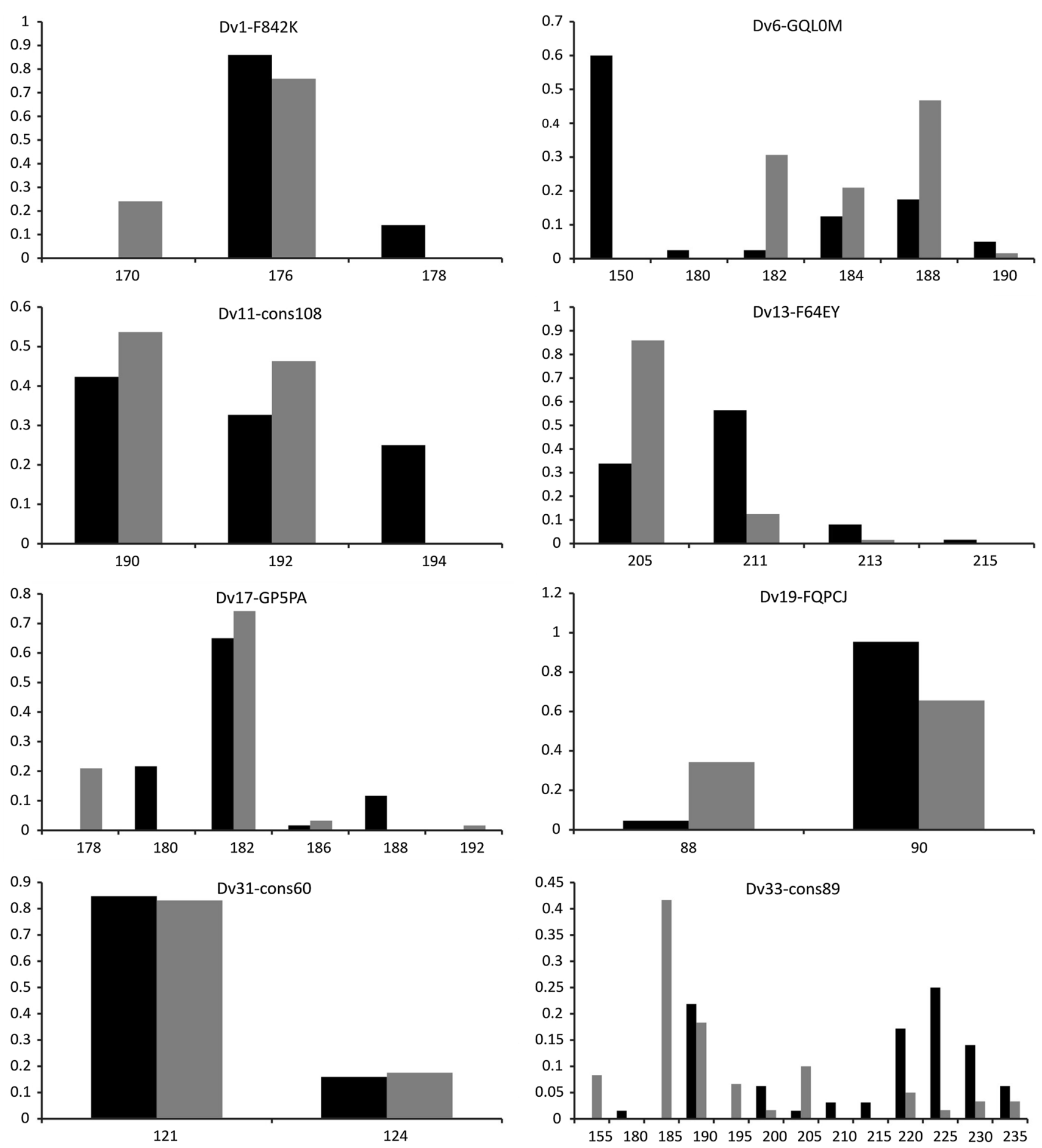

Fig. 1 Allele frequency distribution for each locus for the DAN (black) and DNI (grey) populations. Axis $x$ allele size in bp, axis $y$ frequency of alleles

Dikerogammarus haemobaphes (Eichwald, 1841) and Dikerogammarus bispinosus Martynov, 1925 which are also invasive in European inland waters [28] and, in case of the latter, also in the UK. [29].

Acknowledgments We thank Christine Dubreuil for her help in developing the microsatellite loci, and David Bru from INRA for his kindly assistance in laboratory. The study was founded by the Polish Ministry of Science and Higher Education, Grant N N304 350139, as well as by internal grants and funds from the University of Lodz.

Open Access This article is distributed under the terms of the Creative Commons Attribution License which permits any use, distribution, and reproduction in any medium, provided the original author(s) and the source are credited. 


\section{References}

1. DAISIE (2009) Handbook of alien species in Europe. Springer, Dordrecht. ISBN 978-1-4020-8279-5

2. Bij de Vaate A, Jazdzewski K, Ketelaars HAM, Gollasch S, Van der Velde G (2002) Geographical patterns in range extension of Ponto-Caspian macroinvertebrate species in Europe. Can J Fish Aquat Sci 59:1159-1174

3. Bollache L, Devin S, Wattier R, Chovet M, Beisel JN, Moreteau JC, Rigaud T (2004) Rapid range extension of the Ponto-Caspian amphipod Dikerogammarus villosus in France: potential consequences. Arch Hydrobiol 160:57-66

4. Bącela K, Grabowski M, Konopacka A (2008) Dikerogammarus villosus (Sowinsky, 1894) (Crustacea, Amphipoda) enters Vistula-the biggest river in the Baltic basin. Aquat Invasions 3:95-98

5. Piscart C, Bergerot B, Laffaille P, Marmonier P (2010) Are amphipod invaders a threat to regional biodiversity? Biol Invasions 12:853-863

6. van Riel MC, Velde GVD, Rajagopal S, Marguillier S, Dehairs F, De Vaate AB (2006) Trophic relationships in the Rhine food web during invasion and after establishment of the PontoCaspian invader Dikerogammarus villosus. Hydrobiologia 565:39-58

7. MacNeil C, Platvoet D (2005) The predatory impact of the freshwater invader Dikerogammarus villosus on native Gammarus pulex (Crustacea: Amphipoda); influences of differential microdistribution and food resources. J Zool 267:31-38

8. Dick JTA, Platvoet D, Kelly DW (2002) Predatory impact of the freshwater invader Dikerogammarus villosus (Crustacea: Amphipoda). Can J Fish Aquat Sci 59:1078-1084

9. Bruijs MCM, Kelleher B, Van der Velde G, Bij de Vaate AB (2001) Oxygen consumption, temperature and salinity tolerance of the invasive amphipod Dikerogammarus villosus: indicators of further dispersal via ballast water transport. Arch Hydrobiol 152:633-646

10. Wijnhoven S, Van Riel MC, Van Der Velde G (2003) Exotic and indigenous freshwater gammarid species: physiological tolerance to water temperature in relation to ionic content of the water. Aquat Ecol 37:151-158

11. Brooks SJ, Platvoet D, Mills CL (2008) Cation regulation and alteration of water permeability in the amphipod Dikerogammarus villosus: an indicator of invasion potential. Fundam Appl Limnol 172:183-189

12. Piscart C, Kefford BJ, Beisel JN (2011) Are salinity tolerances of non-native macroinvertebrates in France an indicator of potential for their translocation in a new area? Limnologica 41:107-112

13. Pöckl M (2007) Strategies of a successful new invader in European fresh waters: fecundity and reproductive potential of the Ponto-Caspian amphipod Dikerogammarus villosus in the Austrian Danube, compared with the indigenous Gammarus fossarum and G. roeseli. Freshw Biol 52:50-63

14. Pöckl M (2009) Success of the invasive Ponto-Caspian amphipod Dikerogammarus villosus by life history traits and reproductive capacity. Biol Invasions 11:2021-2041
15. Grabowski M, Bacela K, Konopacka A (2007) How to be an invasive gammarid (Amphipoda: Gammaroidea)-Comparison of life history traits. Hydrobiologia 590:75-84

16. Bacela-Spychalska K, Grabowski M, Rewicz T, Konopacka A, Wattier R (2013) The "killer shrimp" Dikerogammarus villosus (Crustacea, Amphipoda) invading Alpine Lakes: overland transport by recreational boats and scuba-diving gear as potential entry vectors? Aquat Conserv: Mar Freshw Ecosyst 24:606-618

17. MacNeil C, Platvoet D, Dick JTA, Fielding N, Constable A, Hall N, Aldridge D, Renals T, Diamond M (2010) The Ponto-Caspian 'killer shrimp', Dikerogammarus villosus (Sowinsky, 1894), invades the British Isles. Aquat Invasions 5:441-445

18. Wattier RA, Beguet J, Gaillard M, Müller JC, Bollache L, PerrotMinnot M-J (2006) Molecular markers for systematic identification and population genetics of the invasive Ponto-Caspian freshwater gammarid Dikerogammarus villosus (Crustacea, Amphipoda). Mol Ecol Notes 6:487-489

19. Wattier RA, Haine ER, Beguet J, Martin G, Bollache L, Muskó IB, Platvoet D, Rigaud T (2007) No genetic bottleneck or associated microparasite loss in invasive populations of a freshwater amphipod. Oikos 116:1941-1953

20. Kijas JMH, Fowler JCS, Garbett CA, Thomas MR (1994) Enrichment of microsatellites from the citrus genome using biotinylated oligonucleotide sequences bound to streptavidin coated magnetic particles. Biotechniques 16:657-660

21. Malausa T, Gilles A, Meglécz E et al (2011) High-throughput microsatellite isolation through 454 GS-FLX Titanium pyrosequencing of enriched DNA libraries. Mol Ecol Resour 11:683-644

22. Meglécz E, Costedoat C, Dubut V, Gilles A, Malausa T, Pech N, Martin JF (2010) QDD: a user-friendly program to select microsatellite markers and design primers from large sequencing projects. Bioinformatics 26:403-404

23. Goudet J (1995) FSTAT (version 1.2): a computer program to calculate F-statistics. J Hered 86:485-486

24. Wattier R, Engel CR, Saumitou-Laprade P, Valero M (1998) Short allele dominance as a source of heterozygote deficiency at microsatellite loci: experimental evidence at the dinucleotide locus Gv1CT in Gracilaria gracilis (Rhodophyta). Mol Ecol $7: 1569-1573$

25. van Oosterhout C, Hutchinson WF, Wills DPM, Shipley P (2004) Micro-checker: software for identifying and correcting genotyping errors in microsatellite data. Mol Ecol Notes 4:535-538

26. Grabowski M, Jażdżewski K, Konopacka A (2005) Alien crustacea in polish waters (Part I) introduction and decapoda. Oceanol Hydrobiol Stud 24:43-62

27. Huang W, Liang X, Qu C, Cao J, Zhao C, Cao L (2013) Development and characterization of novel polymorphic microsatellite loci in Siniperca scherzeri Steindachner and Siniperca chuatsi (Basilewsky). Mol Biol Rep 40:751-756

28. Labat F, Piscart C, Fontan B (2011) First records, pathways and distributions of four new Ponto-Caspian amphipods in France. Limnologica 41:290-295

29. Gallardo B, Aldridge DC (2013) Priority setting for invasive species management: risk assessment of Ponto-Caspian invasive species into Great Britain. Ecol Appl 23:352-364 